\title{
Electrolytes imbalance caused by amikacin in patients receiving multi drug resistance- tuberculosis treatment at Hazara region Kpk, Pakistan
}

\author{
Faheem JAN 1 \\ Mukhtiar HASSAN ${ }^{1}$ \\ Naveed MUHAMMAD ${ }^{2}$ \\ Shahid WALI ${ }^{3}$ \\ Hafiz Sajid AKBAR ${ }^{4}$ \\ Qazi Mashhood ATTA ${ }^{1}$ \\ Farzana GUL ${ }^{1}$
}

${ }^{1}$ Department of Biochemistry, Hazara University, Mansehra, KPK, Pakistan

${ }^{1}$ Hazara Üniversitesi, Biyokimya Bölümü, Mansehra, KPK, Pakistan

2 Department of Pharmacy, Abdul Wali Khan University, Mardan, KPK, Pakistan

2 Abdul Wali Khan Üniversitesi, Eczacılık Bölümü, Mardan, KPK, Pakistan

3 Programmatic Management of Drug Resistant Unit, Ayub Teaching Hospital, Abbottabad, Pakistan

3 Ilaç Direnci Programı Yönetimi Ünitesi, Ayup Eğitim Hastanesi, Abbottabad, Pakistan

${ }^{4}$ Department of Pharmacy, Abbottabad University of Science and Technology, Abbottabad, Pakistan

4 Abbottabad Bilim ve Teknoloji Üniversitesi, Eczacılık Bölümü,

Abbottabad, Pakistan

\section{SUMMARY}

Electrolytes imbalance caused by amikacin in patients receiving multi drug resistance- tuberculosis treatment at Hazara region Kpk, Pakistan

Introduction: Multi drug resistance-tuberculosis (MDR-TB) is considered amongst one of the fatal medical and public health issue. Greater frequency of adverse reactions has been observed using $2^{\text {nd }}$ line antituberculosis drugs, which rises the rate of morbidity. Hypokalemia and hyponatremia are common in patients receiving MDR-TB treatment.

Materials and Methods: This study was aimed to assess the effect of amikacin as multidrug resistance tuberculosis treatment on serum sodium and potassium level. A total 179 subjects (82 males and 97 females) were screened within the period of one year for their serum electrolyte levels before and during the treatment. Their body weight and sociodemographic characteristics were also taken into considerations. Data were expressed in the form of mean \pm standard error using One-way analysis of variance (ANOVA), followed by Dunnett's test. All the statistical analyses were performed using GraphPad Prism v. 6.

Results: The results showed that amikacin caused a significant $(p<0.05)$ hypokalemia when used in combination with other drugs having no known effect on serum potassium level which proved to be the side effect of amikacin. The average serum potassium level in both intensive and continuation phase was significantly lower ( $p<$ $0.05)$ than the baseline $(3.73 \mathrm{mmol} / \mathrm{L})$, however, in the continuation phase the potassium level $(3.58 \mathrm{mmol} / \mathrm{L})$ was slightly higher than that of intensive phase $(3.54 \mathrm{mmol} / \mathrm{L})$. The average serum sodium

\section{Yazışma Adresi (Address for Correspondence)}

Dr. Faheem JAN

Department of Biochemistry, Hazara University, Mansehra, KPK - PAKISTAN

e-mail: drfaheem82@gmail.com 
Electrolytes imbalance caused by amikacin in patients receiving multi drug resistance- tuberculosis treatment at Hazara region Kpk, Pakistan

level in both phases; intensive and continuation, remained in steady state $(137.25 \mathrm{mmol} / \mathrm{L}$ and $137.87 \mathrm{mmol} / \mathrm{L}$ respectively) throughout the study period as compared to the base line $(135.5 \mathrm{mmol} / \mathrm{L})$. The amikacin drug lowered serum potassium level but had no effect on sodium level.

Conclusion: It is concluded that the serum electrolytes should be monitored during the course of treatment and corrected accordingly.

Key words: Multidrug resistance tuberculosis, amikacin, potassium and sodium

\section{ÖZET}

Pakistan Hazara Kpk bölgesinde çok ilaca dirençli tüberküloz tedavisi alan hastada amikasine bağı gelişen elektrolit dengesizliği

Giriş: Çok ilaca dirençli tüberküloz (ÇiD-TB), en ölümcül tıbbi ve halk sağlığı sorunlarından birisidir. Ikincil anti-tüberküloz ilaç kullanımında daha fazla yan etki görülmektedir ve bu durum morbiditenin artmasına neden olmaktadır. Hipokalemi ve hiponatremi ÇiD-TB tedavisi alan hastalarda sık görülür.

Materyal ve Metod: Bu çalışmanın amacı, ÇiD-TB tedavisinde kullanılan amikasinin serum sodyum ve potasyumu üzerindeki etkisini incelemektir. Toplam 179 olgu (82 erkek, 97 kadın) bir yıl boyunca tedavi öncesi ve sonrası serum elektrolit değerleri açısından tarandı. Vücut ağırıkları ve sosyodemografik özellikleri de dikkate alındı. Veriler ortalama \pm standart hata, ANOVA ve Dunnett's testleriyle değerlendirildi. Tüm istatistiksel analizler GraphPad Prism v. 6 kullanılarak yapıldı.

Bulgular: Sonuçlar amikasinin, serum potasyumu üzerinde etkisi olmadığı bilinen diğer ilaçlarla kullanıldı̆ııda anlam/ı (p< 0.05) hipokalemi yaptığını gösterdi. Serum potasyum seviyeleri, başlangıç ve idame tedavi dönemlerinde tedavi öncesine (3.73 mmol/L) göre anlamlı derecede düşüktü $(p<0.05)$. Ancak idame döneminde potasyum seviyesi $(3.58 \mathrm{mmol} / \mathrm{L})$, başlangıç tedavi dönemine (3.54 mmol/L) göre biraz daha yüksekti. Çalışma dönemi boyunca hem başlangıç hem de idame tedavi dönemindeki serum sodyum seviyeleri (sırasıly $137.25 \mathrm{mmol} / \mathrm{L}$ ve $137.87 \mathrm{mmol} / \mathrm{L}$ ) tedavi öncesi döneme (135.5 mmol/L) göre benzer seyretti. Amikasin serum potasyumunu düşürdüğü halde, sodyum seviyesi üzerine bir etkisi yoktu.

Sonuç: Sonuç olarak tedavi süresince serum elektrolit seviyeleri kontrol edilmeli ve gerektiğinde düzeltilmelidir.

Anahtar kelimeler: Çok ilaca dirençli tüberküloz, amikasin, potasyum, sodyum

\section{INTRODUCTION}

Multidrug resistance tuberculosis (MDR-TB), caused by Mycobacterium tuberculosis strains are resistant to both isoniazid and rifampicin together, and is still a problem for eradication of tuberculosis (TB). According to World Health Organization reports, the prevalence of MDR-TB was $3.6 \%$ for newly reported cases and $20.2 \%$ for already handled cases in 2013 globally (1). Due to increased incidences of drug resistant tuberculosis (DR-TB) in Pakistan, patients are treated through Programmatic Management of Drug Resistant TB (PMDT). For this purpose, different PMDT sites are functional in the country. Ayub Teaching Hospital at Abbottabad (ATH) is one of most sophisticated health care center in the Khyber Pakhtunkhwa Province.

MDR-TB treatment is comprised of four antituberculosis clean drugs to which the $M$. tuberculosis strain is still sensitive including second line injectable antituberculosis (2). All second line injectable drugs are bactericidal having several adverse effects. The second line injectable drugs used in therapy regimen are kanamycin, amikacin and capreomycin (2). Amikacin is used as standardized regimen in Pakistan. On the other hand, caminero has recommended capreomycin as the first choice of second line injectable drug in MDR-TB therapy (2).

Amikacin and capreomycin are classified as antibiotics of aminoglycoside group and cyclic polypeptide (3). They have a disturbance effect on the electrolyte balance, it has been reported that the use of aminoglycoside and capreomycin causes the increase in renal electrolyte wasting including potassium, magnesium, and calcium. Electrolyte disturbance particularly hypokalemia is related to several significant morbidities such as tetany, seizures, and cardiac arrhythmia (3). Therefore, serum potassium level is one of the most significant parameters with respect to the patient's safety.

Diarrhea, vomiting, and excessive sweating are common features in tuberculosis infections as these possible causes for loss of water and electrolyte (4). Fluid, electrolyte and acid-base imbalance commonly found in $\mathrm{TB}$, have been considered as the main factors for development of acute renal failure (5). In view of the water and electrolyte imbalances and the resulting cytochemical changes in MDR-TB, the present study was designed to find out the effect of amikacin on serum electrolytes balance in patients with MDR-TB. 


\section{MATERIALS and METHODS}

\section{Study Population}

The retrospective cohort study was conducted at PMDT-ATH Abbottabad, Pakistan. All confirmed pulmonary MDR-TB patients receiving treatment of MDR-TB from March 2014 to February 2015 were included in the study.

The study population included 139 MDR-TB patients and 40 healthy individuals which were divided into 4 categories:

a. Group 1 (Negative control): This group included those individuals who were free of any disease.

b. Group 2 (G0): This group included all those patients who were eligible for enrollment at PMDT site based on GeneXpert or DST (drug susceptibility testing) but still had not received the treatment of MDR-TB.

c. Group $3(\mathrm{Gl})$ : This group included all those patients who had taken one month of MDR-TB and come for their follow up at PMDT site. Patients in this group were followed up until the completion of their intensive phase of treatment i.e. upto the stoppage of their injectable drug.

d. Group 4 (GC): This group included all those patients who were switched over to their continuation phase of treatment.

\section{Study Design and Settings}

All the enrolled ients were treated on an ambulatory based care model and were appropriately examined on monthly basis by a panel of physicians. All registered patients were first put on a standardized treatment regimen, and subsequently shifted to individualized regimens according to individual's drug susceptibility test results. Data of initial demographic and clinical characteristics of subjects such as age, gender, initial body weight and comorbidities was also recorded. Initial sodium and potassium levels of each patient's serum were monitored during treatment (6). Data was analyzed statistically on monthly basis.

\section{Exclusion Criteria}

\section{Following patients were excluded from the study:}

- Those who had XDR-TB or on injectable capreomycin,

- Those having noncompliance complaints,

- Pregnant women,

- Patients with the history of second line injectable antituberculosis treatment,
- Patients with renal impairment,

- Those taking therapeutic agents which are known to affect serum potassium level such as insulin, angiotensin converting enzyme (ACE) inhibitor, angiotensin II receptor blocker, non-steroidal antiinflammatory drug (NSAID), diuretic, amphotericin $B$, corticosteroid, $\beta 2$-agonis, and potassium supplement.

\section{Ethical Approval}

The study was approved by the institutional review board (IRB), of Ayub Medical Institute, Abbottabad, Pakistan.

\section{Regimen Design and Patient Management}

All the enrolled patients were put on a standardized treatment regimen (STR). The STR was comprised of pyrazinamide, amikacin, levofloxacin, ethionamide, cycloserine, and vitamin B6 (pyridoxine). The drug dosage was individualized according to weight and clinical condition of each patient as per strategy of the National TB Control Program. Treatment on STR was carried out till the receiving of drug susceptibility test (DST) reports. After the confirmation of the resistance pattern determined through DST, all patients were shifted to an individualized treatment regimen (ITR) based on the DST profile of each individual patient (7). In general, regimens contained at least 4 clean drugs based on previous antitubercular therapy (ATT) history and DST result to which the infecting strain was susceptible, as well as a second line injectable drug.

\section{Blood Sample Collection and Analysis of Sodium and Potassium}

Five to seven millimeters of venous blood were obtained from the cubital vein of each patient using a sterile needle and syringe and allowed in plain tube to clot. The plasma was extracted by centrifugation (perfect close system) for 3-5 minutes at $4000 \mathrm{rpm}$ for analysis of sodium and potassium level. The serum was analyzed using an automatic electrolyte analyzer (Easylyte model \# 9180 made by Roche Company) and the results were recorded. All the chemicals used were of diagnostic grade.

\section{Statistical Analysis}

All the data expressed in the form of mean \pm standard error. One-way analysis of variance (ANOVA) was carried out followed by Dunnett's test. All the statistical analyses were performed using GraphPad Prism v. 6 (GraphPad Software, San Diego, California, USA). 


\section{RESULTS}

\section{Initial Demographic Characteristic of Patients}

Characteristics of patients like gender, educational status, initial demographic and socio-economic conditions are presented in Table 1. Table 2 shows that the average weight of the patients was significantly $(p<0.05)$ improved during study duration which is a clear indication for repression of the infection. The weight based dosage of MDR-TB according to WHO is presented in Table 3 (8).

\section{Serum Sodium level}

When sodium level of both male and female patients was analyzed it was found that the highest value of sodium was observed in male patients at GC4 (139.9 \pm 3.5 ) of age group upto 40 years, while the lowerest value observed in male of age groups upto 20 years $(132.6 \pm 6.4)$ as in Table 4.

In male of age upto 20 years the highest value was recorded at Gl8 $(138.3 \pm 6)$ and the lowerest observed value was $(132.6 \pm 6.4)$ at G0 treatment phase. Significant variation $(p<0.01)$ in this age group was occurred at G0. For female of the same age group the highest value was observed at GC2 $(138.8 \pm 4.5)$, while the lowerest value was at Gl3 $(136.2 \pm 5.1)$. In female no such significant variation was observed.

When male of the age upto 40 years were analyzed for their level of sodium it was found that the highest value was observed at GC4 (139.9 \pm 3.5$)$, while the lowerest value was observed at G0 $(135.9 \pm 4.2)$. For female of this age group the highest value was reported at GI7 (138.3 \pm 3.2$)$, and lowerest value ( $p$ $<0.01)$ was at G0 $(134.8 \pm 5.6)$ treatment phase. For male of this age group no significant variation noted while for female the significant variations $(p<0.01)$ were observed at $\mathrm{G} 0$ and $\mathrm{Gl} 2$ respectively.

For male of age above 40 years the highest value of sodium was noted at Gl6 $(139 \pm 4.1)$, and the lowerest value was at Gl1 $(135.2 \pm 6.9)$, while in case of female of this age group the highest observed value was at GC3 $(138 \pm 3.1)$ and the lowerest one at GC1 $(135.1 \pm 4.3)$. In this age group for both sex no such significant variation was observed.

\section{Serum Potassium level}

Mean potassium level of the patients distributed with in three age groups separately for male and female was found highest in above 40 years of age group for

\section{Table 1. Characteristics of patients}

\begin{tabular}{|lll|}
\hline \multicolumn{2}{|c|}{ Patient characteristics } & No of patients in \% \\
\hline Gender & Males & $62(44.6 \%)$ \\
\multirow{3}{*}{ Residence } & Females & $77(55.4 \%)$ \\
& Urban & $25(18 \%)$ \\
Marital status & Rural & $114(82 \%)$ \\
& Married & $89(64 \%)$ \\
& Unmarried & $49(35.3 \%)$ \\
Educational status & Widow & $1(0.7 \%)$ \\
& Illiterate & $93(66.90 \%)$ \\
Socioeconomic & Literate & $46(33.1 \%)$ \\
condition & Upper class & $1(0.7 \%)$ \\
& Medal class & $27(19.42 \%)$ \\
\hline \multirow{2}{*}{ Lower class } & $111(79.85 \%)$ \\
\hline
\end{tabular}

male $(4 \pm 0.91)$ in G0 treatment phase and for female in GC3 treatment phase which is $(3.93 \pm 1.12)$ in same age group. While the lowerest values $(p<$ 0.001 ) for male lies in upto 20 years of age group in GC2 treatment phase $(3.22 \pm 0.5)$, and for female it was $(3.22 \pm 0.54)$ in age group above 40 years at treatment phase with significant $(p<0.05)$ Gl4 (Table 5).

Significant variation $(p<0.05, p<0.01$ and $p<0.001)$ with respect to potassium serum level in group upto 20 years of age was found in Gl3, Gl5, Gl6, Gl7, GC1, GC2 and GC3 respectively for male patients, while in this age group female showed no variation. In group upto age 40 years, both male and female patients showed a prominent and significant variation $(p<0.05, p<0.01$ and $p<0.001)$ almost in all treatment phase except Negative control and GC4 for male and only NC for female patients. A serum potassium level in age group above 40 years of male patients showed no significant variation, while that of female patients reflect variation $(p<0.05)$ only in treatment phase GI2 and GI4.

\section{DISCUSSION}

The study of socioeconomic status of the patients revealed that TB was converted to MDR-TB mostly in females $(55.40 \%)$. In Pakistan females are more immuno compromised and also limited to home in most of their life span, so the restricted environment, improper ventilation and poor hygienic conditions are responsible for such type of infections. In rural areas, due to lack of transportation and health care units the MDR-TB cases are more prevalent as compared to urban areas. In Pakistan, the literacy rate lower in rural areas than the urban areas. Due to lack 
Jan F, Hassan M, Muhammad N, Wali S, Akbar HS, Atta QM, Gul F.

\begin{tabular}{|c|c|c|c|c|c|c|c|c|c|c|}
\hline & $\underset{\cup}{\circlearrowright}$ & \multirow{14}{*}{ 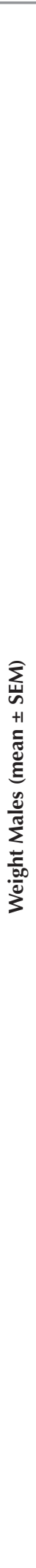 } & $\begin{array}{l}\stackrel{*}{*} \\
\stackrel{n}{*} \\
\stackrel{+}{+} \\
+1 \\
\stackrel{1}{n}\end{array}$ & 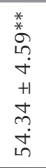 & 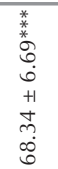 & \multirow{14}{*}{ 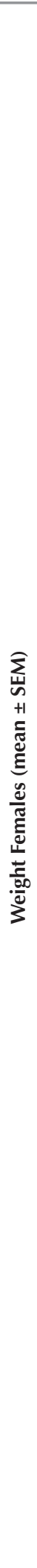 } & 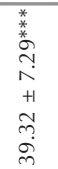 & 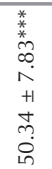 & 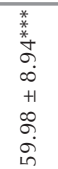 & \\
\hline 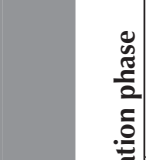 & U & & $\begin{array}{l}\stackrel{*}{*} \\
\stackrel{0}{*} \\
\underset{\sim}{+1} \\
+1 \\
\stackrel{g}{q}\end{array}$ & 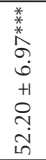 & $\begin{array}{l}\text { 窭 } \\
\stackrel{0}{c} \\
+1 \\
+1 \\
\\
\hat{0}\end{array}$ & & 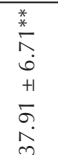 & 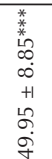 & 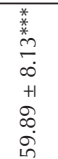 & \\
\hline 胥 & Uु & & $\begin{array}{l}\stackrel{*}{*} \\
\stackrel{*}{*} \\
m \\
+ \\
+1 \\
\infty \\
+\end{array}$ & 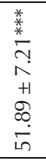 & 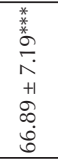 & & 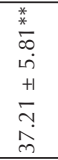 & 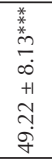 & 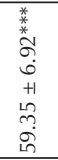 & \\
\hline & $\bar{U}$ & & $\begin{array}{l}\frac{*}{*} \\
\text { in } \\
m \\
+1 \\
+1 \\
b \\
+\end{array}$ & 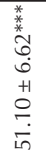 & 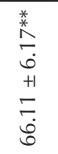 & & 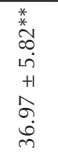 & 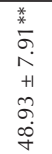 & 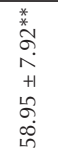 & \\
\hline & $\frac{\infty}{U}$ & & 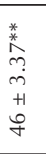 & 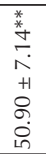 & 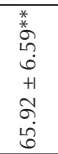 & & 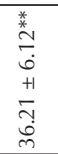 & 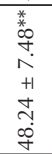 & 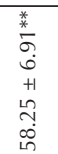 & \\
\hline & $\bar{v}$ & & 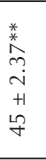 & 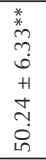 & 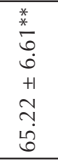 & & 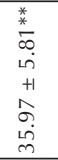 & 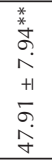 & 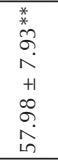 & \\
\hline & $\frac{0}{0}$ & & $\begin{array}{l}\stackrel{*}{*} \\
\\
+ \\
+1 \\
+ \\
\dot{f}\end{array}$ & 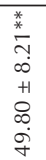 & 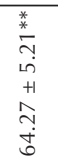 & & 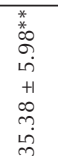 & 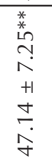 & 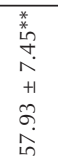 & $\dot{\bar{\delta}}$ \\
\hline 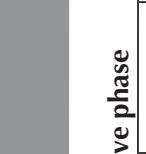 & $\frac{\operatorname{Ln}}{0}$ & & $\begin{array}{l}\stackrel{*}{*} \\
\hat{m} \\
m \\
+1 \\
\dot{f}\end{array}$ & 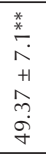 & 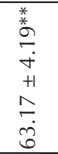 & & 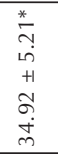 & 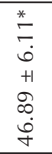 & 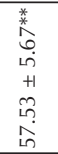 & 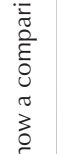 \\
\hline $\begin{array}{l}\bar{c} \\
\overline{0} \\
\underline{\underline{s}}\end{array}$ & $\frac{\mathrm{J}}{\mathrm{U}}$ & & 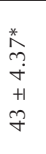 & 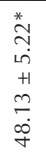 & 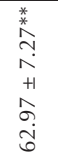 & & 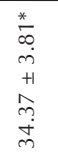 & 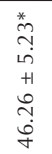 & 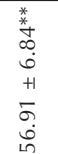 & $\begin{array}{l}\bar{n} \\
\bar{o} \\
0 \\
0 \\
v \\
v \\
a \\
\frac{*}{*}\end{array}$ \\
\hline & $\frac{m}{U}$ & & 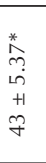 & $\begin{array}{l}\text { * } \\
\stackrel{0}{0} \\
+1 \\
\sigma \\
\stackrel{+}{f}\end{array}$ & 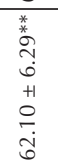 & & 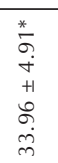 & 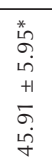 & 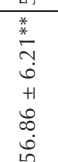 & 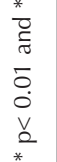 \\
\hline & $\frac{1}{0}$ & & 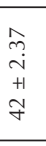 & 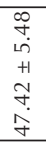 & $\begin{array}{l}\bar{\sigma} \\
\dot{10} \\
+1 \\
0 \\
0 \\
\bar{\sigma}\end{array}$ & & 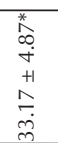 & 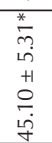 & $\begin{array}{l}\frac{n}{*} \\
0 \\
0 \\
n \\
+1 \\
+1 \\
0 \\
0 \\
0 \\
0\end{array}$ & $\begin{array}{l}*^{*} \\
2 \\
0 \\
\dot{0} \\
v \\
2 \\
*\end{array}$ \\
\hline 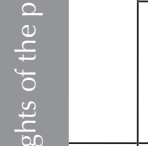 & $\overline{\bar{U}}$ & & $\begin{array}{l}\hat{m} \\
\hat{m} \\
+1 \\
o\end{array}$ & $\begin{array}{l}\bar{N} \\
\omega n \\
+1 \\
\infty \\
\infty \\
\vdots \\
\dot{y} \\
+\end{array}$ & $\begin{array}{l}\hat{\sigma} \\
\dot{+} \\
+ \\
+1 \\
+ \\
0 \\
\dot{0} \\
0\end{array}$ & & \begin{tabular}{l} 
\\
\multirow{+}{+}{} \\
+1 \\
+ \\
$\sigma$ \\
$\tilde{d}$
\end{tabular} & 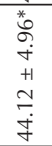 & 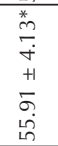 & 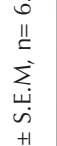 \\
\hline $\begin{array}{l}3 \\
\mathbf{z} \\
\mathbf{z}\end{array}$ & ○ & & $\begin{array}{l}\hat{N} \\
\stackrel{+}{+} \\
+1 \\
\tilde{N} \\
\stackrel{+}{+}\end{array}$ & $\begin{array}{l}\text { 3̧ } \\
\dot{+} \\
+1 \\
\hat{n} \\
\tilde{\sigma}\end{array}$ & 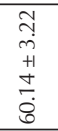 & & 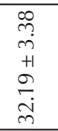 & 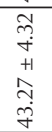 & 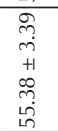 & 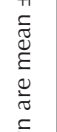 \\
\hline$\underset{<}{0}$ & & & $\begin{array}{l}\hat{n} \\
\\
+1 \\
+1 \\
\infty \\
g \\
0 \\
0\end{array}$ & 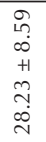 & 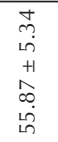 & & 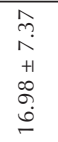 & 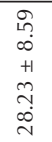 & 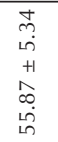 & $\begin{array}{l}\frac{3}{0} \\
\frac{0}{4} \\
y \\
\frac{0}{3} \\
\frac{\pi}{5}\end{array}$ \\
\hline
\end{tabular}


Electrolytes imbalance caused by amikacin in patients receiving multi drug resistance- tuberculosis treatment at Hazara region Kpk, Pakistan

Table 3. Weight based dosing of MDR-TB medicines

\begin{tabular}{|c|c|c|c|c|c|c|c|}
\hline S.No & Drugs & Daily dose & $30-35 \mathrm{~kg}$ & $36-45 \mathrm{~kg}$ & $46-55 \mathrm{~kg}$ & $56-70 \mathrm{~kg}$ & $>70 \mathrm{~kg}$ \\
\hline 1 & Pyrazinamide & $20-30 \mathrm{mg} / \mathrm{kg}$ once daily & $800 \mathrm{mg}$ & $1000 \mathrm{mg}$ & $1200 \mathrm{mg}$ & $1600 \mathrm{mg}$ & $2000 \mathrm{mg}$ \\
\hline 2 & Levofloxacin & 750-1000 mg once daily & $750 \mathrm{mg}$ & $750 \mathrm{mg}$ & $1000 \mathrm{mg}$ & $1000 \mathrm{mg}$ & $1000 \mathrm{mg}$ \\
\hline 3 & Cycloserine & $500-750 \mathrm{mg} /$ day in 2 divided doses & $500 \mathrm{mg}$ & $500 \mathrm{mg}$ & $500 \mathrm{mg}$ & $750 \mathrm{mg}$ & 750 mg \\
\hline 4 & Ethionamide & $500-750 \mathrm{mg} /$ day in 2 divided doses & $500 \mathrm{mg}$ & $500 \mathrm{mg}$ & $750 \mathrm{mg}$ & $750 \mathrm{mg}$ & $1000 \mathrm{mg}$ \\
\hline 5 & Pyridoxine & $500-750 \mathrm{mg} /$ day in 2 divided doses & $500 \mathrm{mg}$ & $500 \mathrm{mg}$ & $500 \mathrm{mg}$ & $750 \mathrm{mg}$ & $750 \mathrm{mg}$ \\
\hline \multicolumn{8}{|c|}{ Weight-based injectable anti-TB daily dosing in adults $\geq 30 \mathrm{~kg}$} \\
\hline & Amikacin & $15-20 \mathrm{mg} / \mathrm{kg}$ once daily & $500 \mathrm{mg}$ & $625 \mathrm{mg}$ & $750 \mathrm{mg}$ & $875 \mathrm{mg}$ & $1000 \mathrm{mg}$ \\
\hline
\end{tabular}

education in the society, the proper medical care is not provided to the patients and ultimately normal cases of infections are converted to serious diseases like MDR-TB which might be prevented, if the care givers belonging to rural areas are properly educated. Poor financial condition of the people is another major cause of TB, due to which the patients do not approach to the qualified physician and usually compelled to relay on the locally available nonprofessional and uneducated quacks, Hakeem's or on spiritual treatment (Dam Darood). The close contact of the patient with care givers or other relatives also lead to spread the infection and cause severity of this contagious disease. It is observed more commonly among married population in case of TB.

One of the typical symptoms of TB is anorexia and weight loss $(9,10)$. It was observed during this study that the MDR-TB patients were suffering from such significant symptoms when they visited PMDT. With the passage of time it was noted that patients were gaining weight during MDR-TB treatment regimen. But this improvement was more common in males as compared to females. The improving in body weight clearly indicated that this change was because of the diminished anorexia and prognosis of infection.

The therapy recommended for MDR-TB by WHO includes amikacin, pyrazinamide, cycloserine, ethionamide, levofloxacin and vitamin B6. among these amikacin (the aminoglycosides) are notorious for their nephrotoxicity, hypokalemia and ototoxicity $(11,12)$. The continuous use of amikacin in this study led to the electrolyte imbalance especially hypokalemia in patients after treatment. A study on animals showed that the use of amikacin for 7 day caused hyponatremia (13). The reason of nephrotoxicity associated with amikacin is that it is a powerful cationic drug which attaches to negatively charged acidic phosphoinositide component on the brush border membrane of proximal tubule. After attachment to the brush border amikacin reaches cationic drug receptor megalin situated deep at the brush border of villi, resulting in the formation of drug receptor complex, which is quickly incorporated by pinocytosis and taken up by lysosomes where progression of lysosomal, phospholipidosis occurs resulting in development of classic morphologic myeloid bodies. After their entrance into the S1 and S2 segments of proximal tubule, most of the intracellular processes are altered by the existence of amikacin (14-16). The possible nephrotoxic effect of amikacin depends upon the number of free amino groups on their surface $(17,18)$.

It is clear from our results that the MDR-TB medication in combination causes a significant $(p<0.05)$ hypokalemia, which is attributed specially to the amikacin. Now this toxic condition can be minimized or eradicated if some researchers try to find out an equipotent and effective antibiotic as substitution for amikacin.

On the other hand, we have unexpected results regarding serum sodium level. This treatment regimen does not cause any remarkable alteration in sodium level. Although perversions study showed that there was a significant decrease of serum sodium levels in patients receiving amikacin when compared with control group (13). The mechanism explaining the hyponatremic effect of amikacin is the activation of CaSR receptor present in the thick ascending limb of loop of Henle. Stimulation of CaSR results in the alteration of electrolyte transportation through 
Jan F, Hassan M, Muhammad N, Wali S, Akbar HS, Atta QM, Gul F.

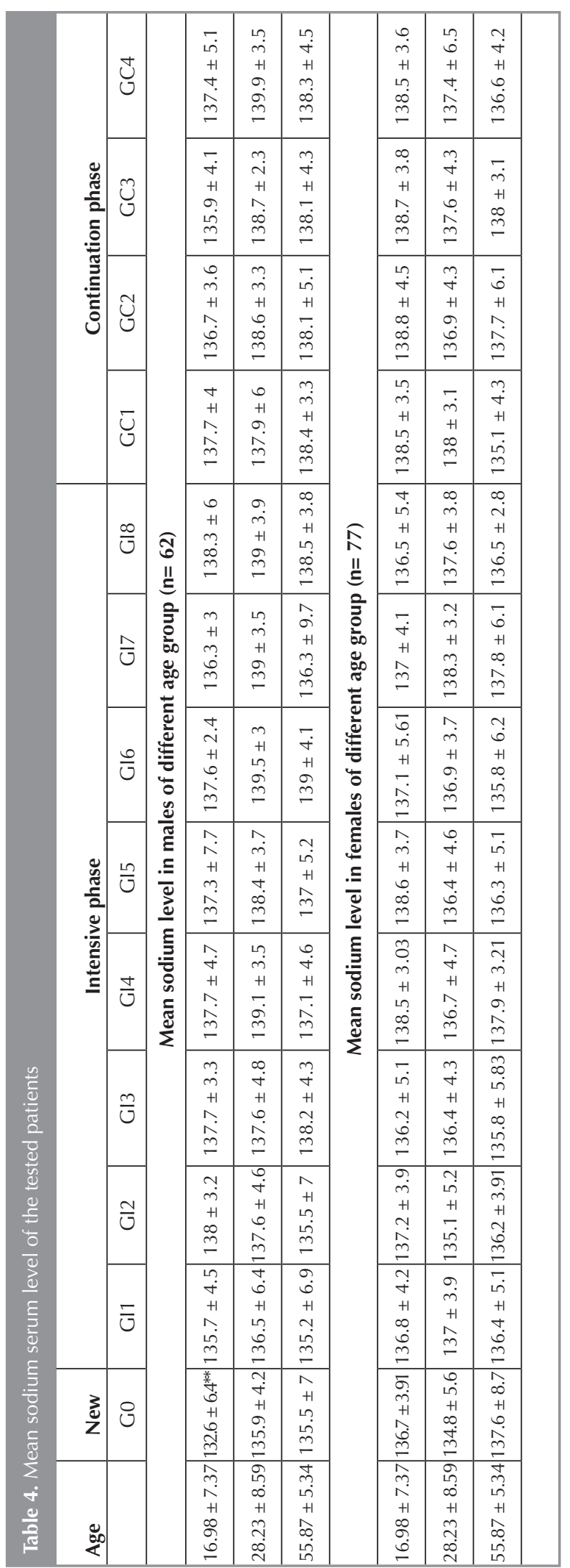




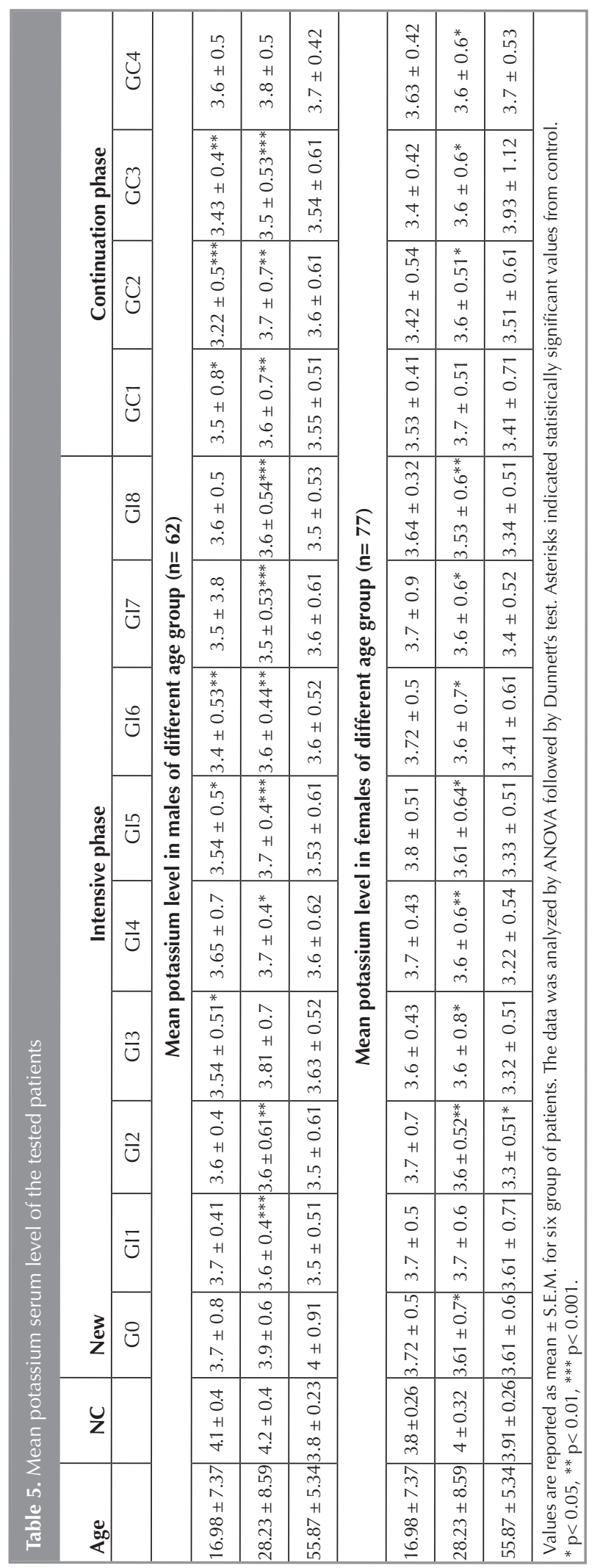

200 Tuberk Toraks 2017;65(3):193-201 
inhibition of four pathways involving $\mathrm{Na}^{+}, \mathrm{K}^{+}, \mathrm{Cl}^{-}$ symporter channel (NKCC2), renal outer medullary potassium channel (ROMK), $\mathrm{Na}^{+}, \mathrm{K}^{+}$-ATPase and/or paracellular diffusion. Inhibition of these transport mechanism leads to improved urinary excretion of $\mathrm{Na}^{+}, \mathrm{K}^{+}, \mathrm{Mg}^{+}$, and $\mathrm{Ca}_{2}{ }^{+}$and associated electrolyte disorders (19). It may be possible that the hyponatremic effect of these drugs might be counteracted by adjunct drugs. However, we strongly recommend further study on this combination to confirm the imbalance of serum sodium level.

\section{CONCLUSION}

The study suggests that all the PMDT (Programmatic Management of Drug Resistant Tuberculosis) sites having MDR-TB patients should closely be monitored for the electrolyte levels especially those on injectable, and if found unusual, they should be corrected accordingly. At the same time the risk factors include acute or chronic diarrhea, vomiting, uncontrolled diabetes, Addison's disease, heat exhaustion, taking a diet inadequate in sodium and potassium specially in old age, kidney diseases, Cushing' syndrome, aldosteronism, loss of body fluids leading to dehydration, excessive alcohol consumption, high grade fever and/or concomitant administration of other drugs that cause electrolyte imbalance. The socioeconomic conditions of the patients should also be improved and proper counseling of the patient about the sign and symptoms of electrolyte imbalance advised.

\section{CONFLICT of INTEREST}

The authors declare that there is no conflict of interest regarding the publication of this manuscript.

\section{REFERENCES}

1. Berggren R, Batuman V. HIV-associated renal disorders: recent insights into pathogenesis and treatment. Curr HIV/ AIDS Rep 2005;2:109-15.

2. Caminero JA, Sotgiu G, Zumla A, Migliori GB. Best drug treatment for multidrug-resistant and extensively drugresistant tuberculosis. Lancet Infect Dis 2010;10:621-9.

3. Carlier MB, Rollman B, Van Hoof F, Tulkens P. Mechanism of aminoglycoside-induced lysosomal phospholipidosis: in vitro and in vivo studies with gentamicin and amikacin. Biochem Pharmacol 1982;31:3861-70.
4. Douglas and Bennett principles and practice of... Mandell, Dolin R, Mandell GL. Principles and practice of infectious diseases. Churchill Livingstone, 1995.

5. Gonzalez LS, Spencer JP. Aminoglycosides: a practical review. Am Fam Physician 1998;58:1811-20.

6. Grieco MH, Chmel H. Acute disseminated tuberculosis as a diagnostic problem: a clinical study based on twenty-eight cases 1. Am Rev Respir Dis 1974;109:554-60.

7. Helen S, Rustam R. Hypokalemia in adults. Share Care Pathology Guidelines CHISCP6. 2012.

8. Katherine F, Annabel B, Anna D, Hannah MD, Dennis F, Ines $G$, et al. Global tuberculosis report. France: WHO Library Cataloguing-in-Publication Data. 2013.

9. Luft FC, Bloch R, Sloan RS, Yum MN, Costello R, Maxwell $D R$. Comparative nephrotoxicity of aminoglycoside antibiotics in rats. J Infect Dis 1978;138:541-5.

10. Melnick IZ, Baum M, Thompson JR. Aminoglycosideinduced Fanconi's syndrome. Am J Kidney Dis 1994;23: 118-22.

11. Moestrup SK, Cui S, Vorum H, Bregengard C, Bjorn SE, Norris K, et al. Evidence that epithelial glycoprotein 330/ megalin mediates uptake of polybasic drugs. J Clin Invest 1995;96:1404.

12. Onwuliri VA. Total bilirubin, albumin, electrolytes and anion gap in HIV positive patients in Nigeria VA Onwuliri. J Med Sci 2004; 4:214-20.

13. Sahn SA, Neff TA. Miliary tuberculosis. Am J Med 1974; 56:495-505.

14. Shin S, Furin J, Alcantara F, Hyson A, Joseph K, Sanchez E, et al. Hypokalemia among patients receiving treatment for multidrug-resistant tuberculosis. Chest J 2004;125: 974-80.

15. Tabarsi P, Chitsaz E, Tabatabaei V, Baghaei P, Shamaei M, Farnia $P$, et al. Revised Category II regimen as an alternative strategy for retreatment of Category I regimen failure and irregular treatment cases. Am J Ther 2011;18:343-9.

16. Williams $P D$, Bennett $D B$, Gleason $C R$, Hottendorf $G H$. Correlation between renal membrane binding and nephrotoxicity of aminoglycosides. Antimicrob Agents Chemother 1987;31:570-4.

17. World Health Organization. Companion Handbook to the 2011 Who Guidelines for the Programmatic Management of Multidrug-resistant Tuberculosis. 2015.

18. Zahid M, Ahmed S, Anjum S. Electrolyte imbalance associated with Aminoglycosides-An experimental study. P J M H S 2013;7:1090-3.

19. Zietse R, Zoutendijk R, Hoorn EJ. Fluid, electrolyte and acidbased disorders associated with antibiotic therapy. Nat Rev Nephrol 2009;5:193-202. 